\title{
PENGEMBANGAN MODUL AJAR APLIKASI BASIS DATA DENGAN MODEL PEMBELAJARAN SQ3R UNTUK SISWA KELAS X REKAYASA PERANGKAT LUNAK DI SMK NEGERI 1 NEGARA
}

\author{
oleh \\ Ni Putu Prita Nugrahini, NIM 1015057096 \\ Pembimbing I: Made Windu Antara Kesiman, S.T.,M.Sc \\ Pembimbing II: I Gede Mahendra Darmawiguna, S.Kom.,M.Sc \\ Jurusan Pendidikan Teknik Informatika
}

\begin{abstract}
ABSTRAK
Penelitian ini bertujuan untuk (1) merancang dan mengimplementasi pengembangan modul ajar aplikasi basis data dengan model pembelajaran SQ3R untuk siswa kelas $X$ Rekayasa Perangkat Lunak di SMK Negeri 1 Negara; (2) menganalisis respon siswa terhadap pengembangan modul ajar aplikasi basis data dengan model pembelajaran SQ3R untuk siswa kelas X Rekayasa Perangkat Lunak di SMK Negeri 1 Negara. Pengembangan modul ajar ini dilakukan karena melihat permasalahan di lapangan dimana pemahaman kepada siswa kurang dan lambat dalam pemahaman konsep materi pembelajaran dan buku pedoman yang dimiliki siswa sangatlah kurang.

Penelitian ini merupakan penelitian pengembangan dengan model pembelajaran SQ3R (Survey, Question, Read, Recite, Review) atau di sebut juga dengan metode membaca cepat. Penelitian yang dilakukan sampai pada tahap pengembangan dan menganalisis respon siswa terhadap modul ajar yang dikembangkan. Model pengembangan yang digunakan mengacu pada model pengembangan Model Dick and Carrey. Modul ajar yang telah dikembangkan di uji coba oleh siswa kelas X Rekayasa Perangkat Lunak di SMK Negeri 1 Negara untuk diketahui respon siswanya. Penelitian ini mengambil populasi kelas X Rekayasa Perangkat Lunak di SMK Negeri 1 Negara dengan sampel penelitian kelas X RPL 2 dengan jumlah siswa sebanyak 35 orang.

Berdasarkan hasil penelitian dari jumlah presentase respon siswa terhadap pengembangan modul ajar Aplikasi Basis Data dapat dikategorikan sangat positif. Respon sangat positif tersebut menunjukkan bahwa siswa senang dan termotivasi dalam belajar dengan menggunakan modul ajar. Hal ini disebabkan karena modul ajar ini berisi gambar - gambar untuk bahan diskusi, materi yang jelas langkah - langkahnya dan terorganisasi, terdapat rangkuman dan soal latihan untuk mengukur pemahaman siswa terhadap materi yang telah di paparkan serta bagian akhir dari modul ajar setelah mempelajari ke 6 bab terdapat bagian review, dimana siswa merangkum seluruh materi dari ke 6 bab pada lembar yang telah disediakan. Sehingga siswa lebih mengerti dan memahami isi materi Aplikasi Basis Data.
\end{abstract}

Kata kunci : aplikasi basis data, modul ajar, SQ3R, respon siswa

\section{PENDAHULUAN}

1.1 Latar Belakang

Untuk meningkatkan mutu pendidikan, di Indonesia telah diupayakan dengan berbagai cara atau strategi oleh pemerintah. Upaya-upaya pemerintah sudah merambah hampir ke semua komponen pendidikan seperti penambahan jumlah buku-buku pelajaran, peningkatan kualitas guru, pembaharuan kurikulum dan peningkatan kualitas pembelajaran yang mencakup pembaharuan dalam model, pendekatan dan media dalam proses pembelajaran. Selain itu, mata pelajaran telah menggunakan kurikulum KTSP baik dari model pembelajarannya sampai pada pengaplikasiannya. Namun pada pelaksanaannya 


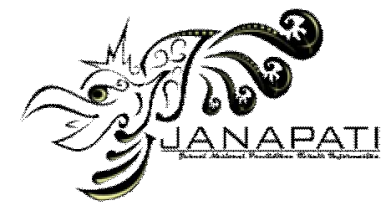

ISSN 2089-8673

Jurnal Nasional Pendidikan Teknik Informatika (Janapati)

Volume 1, Nomor 3, Desember 2012

masih banyak mengalami permasalahan karena tidak menerapkan model pembelajaran yang tepat dalam kesesuaian materi kurikulum yang diterapkan saat ini di sekolah-sekolah adalah Kurikulum

Salah satu masalah penting yang sering dihadapi oleh guru dalam kegiatan pembelajaran adalah memilih atau menentukan bahan ajar atau materi pembelajaran yang tepat dalam rangka membantu siswa mencapai kompetensi. Bahan ajar atau materi pembelajaran secara garis besar terdiri dari pengetahuan, keterampilan, dan sikap yang harus dipelajari siswa dalam rangka mencapai standar kompetensi yang telah ditentukan. Bahan ajar merupakan salah satu komponen sistem pembelajaran yang memegang peranan penting dalam membantu siswa mencapai Standar Kompetensi dan Kompetensi Dasar atau tujuan pembelajaran yang telah ditentukan (Suparmin dan Desy, 2010).

Dari hasil wawancara dengan guru mata pelajaran aplikasi basis data khususnya untuk kelas X Rekayasa Perangkat Lunak, selama ini proses pembelajarannya belum menggunakan modul ajar sebagai panduan belajar. Sumber belajar yang digunakan selama ini hanya didapat dari internet, sehingga materi belum terorganisasi dengan baik. Menyikapi dari permasalahan sumber belajar yang kurang, maka diperlukannya jalan keluar sehingga siswa dapat seoptimal mungkin untuk terlibat dalam proses belajar mengajar baik di sekolahnya maupun dirumahnya.

Salah satu upaya yang dapat di tempuh adalah melalui pengembangan modul ajar dengan model pembelajaran SQ3R. Modul ajar merupakan suatu cara pengorganisasian materi pelajaran yang memperhatikan fungsi pendidikan. Melalui pengorganisasian materi ini siswa diharapkan dapat mencapai dan menguasai materi pelajaran sesuai dengan waktu yang disediakan. Dengan model pembelajaran SQ3R (Survey, Question, Read, Recite, Review), siswa dapat menggunakan modul ajar ini sebagai media pembelajaran dalam proses belajar - mengajar dengan teknik membaca dan memahami materi secara cepat. Berdasarkan latar belakang masalah, penulis ingin mengembangkan modul ajar dalam penelitian yang berjudul "Pengembangan Modul Ajar Aplikasi Basis Data Dengan Model Pembelajaran SQ3R Untuk Siswa Kelas X Rekayasa Perangkat Lunak Di SMK Negeri 1 Negara.

1.2 Rumusan Masalah

Berdasarkan uraian latar belakang di atas adapun permasalahan yang akan dikaji dalam penelitian ini dirumuskan sebagai berikut.

1. Bagaimana rancangan dan implementasi pengembangan modul ajar aplikasi basis data dengan model pembelajaran SQ3R untuk siswa kelas X Rekayasa Perangkat Lunak di SMK Negeri 1 Negara

2. Bagaimana respon siswa terhadap pengembangan modul ajar aplikasi basis data dengan model pembelajaran SQ3R untuk siswa kelas X Rekayasa Perangkat Lunak di SMK Negeri 1 Negara.

\section{KAJIAN PUSTAKA}

\subsection{Modul Ajar}

Modul ajar adalah suatu cara pengorganisasian materi pelajaran yang memperhatikan fungsi pendidikan. Strategi pengorganisasian materi pembelajaran terdiri dari tiga tahapan proses berpikir, yaitu pembentukan konsep, intepretasi konsep, dan aplikasi prinsip. Strategi-strategi tersebut memegang peranan sangat penting dalam mendesain pembelajaran. Model pengembangan modul merupakan seperangkat prosedur yang dilakukan secara berurutan untuk melaksanakan pengembangan sistem pembelajaran modul.

\subsection{Peranan Modul Ajar Dalam Pembelajaran}

Pembelajaran dengan modul adalah pendekatan pembelajaran mandiri yang berfokuskan penguasaan kompetensi dari bahan kajian yang dipelajari peserta didik dengan waktu tertentu sesuai dengan potensi dan kondisinya. Belajar mandiri adalah suatu proses di mana individu mengambil inisiatif dengan atau tanpa bantuan orang lain untuk mendiagnosa kebutuhan belajarnya sendiri; merumuskan/menentukan tujuan belajarnya 


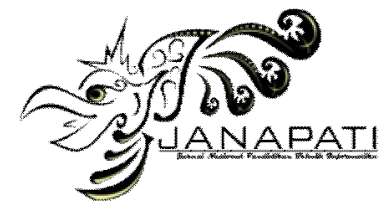

ISSN 2089-8673

Jurnal Nasional Pendidikan Teknik Informatika (Janapati)

Volume 1, Nomor 3, Desember 2012

sendiri; mengidentifikasi sumber-sumber belajar; memilih dan melaksanakan strategi belajarnya; dan mengevaluasi hasil belajarnya sendiri.

\subsection{Model Pembelajaran}

Model pembelajaran adalah suatu perencanaan atau suatu pola yang digunakan sebagai pedoman dalam merencanakan pembelajaran di kelas atau pembelajaran tutorial dan untuk menentukan perangkat-perangkat pembelajaran, termasuk di dalamnya bukubuku, film, komputer, kurikulum, dan lain-lain. Model pembelajaran SQ3R ditemukan oleh F.P Robinson dari Universitas Ohio State pada tahun 1940. Model pembelajaran SQ3R adalah model pembelajaran yang mencakup lima kegiatan belajar yaitu survey, question, read, recite, dan review (Fisher, 1990).

\subsection{Strategi Penyampaian Pembelajaran}

Strategi penyampaian pembelajaran menekankan pada media apa yang dipakai untuk menyampaikan pembelajaran, kegiatan belajar apa yang dilakukan siswa, dan struktur belajar mengajar bagaimana yang dilakukan. Dalam hal ini media pembelajaran merupakan satu komponen penting dari strategi penyampaian pembelajaran. Itulah sebabnya, media pembelajaran merupakan bidang kajian utama strategi ini (Degeng, 1989).

\section{METODE PENELITIAN}

Metode penelitian dan pengembangan atau dalam bahasa inggrisnya Research and Development adalah metode penelitian yang digunakan untuk menghasilkan produk tertentu, dan menguji keefektifan produk tersebut. Untuk dapat menghasilkan produk tertentu digunakan penelitian yang bersifat analisis kebutuhan dan untuk menguji keefektifan produk tersebut supaya dapat berfungsi di masyarakat luas, maka diperlukan penelitian untuk menguji keefektifan produk tersebut. Jadi penelitian dan pengembangan bersifat longitudinal (bertahap bias multy years) (Sugiyono,2011)

Penelitian ini merupakan penelitian pengembangan modul ajar aplikasi basis data dengan model pembelajaran SQ3R untuk siswa kelas X Rekayasa Perangkat Lunak di SMK Negeri 1 Negara. Model pengembangan yang digunakan mengacu pada model pengembangan Model Dick and Carrey.

Berikut adalah tahapan-tahapan yang dilakukan dalam pengembangan draf pembelajaran yang ditunjukkan pada gambar berikut.

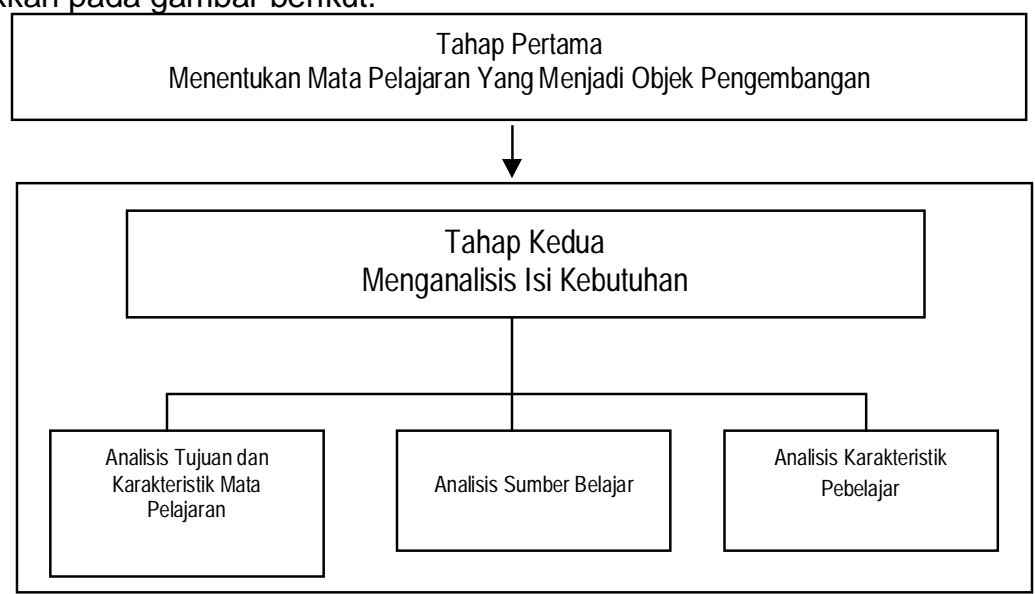

Gambar 3.1 Tahap Pertama dan Kedua Pengembangan Modul (Trianto, 2007) 
ISSN 2089-8673

Jurnal Nasional Pendidikan Teknik Informatika (Janapati)

Volume 1, Nomor 3, Desember 2012

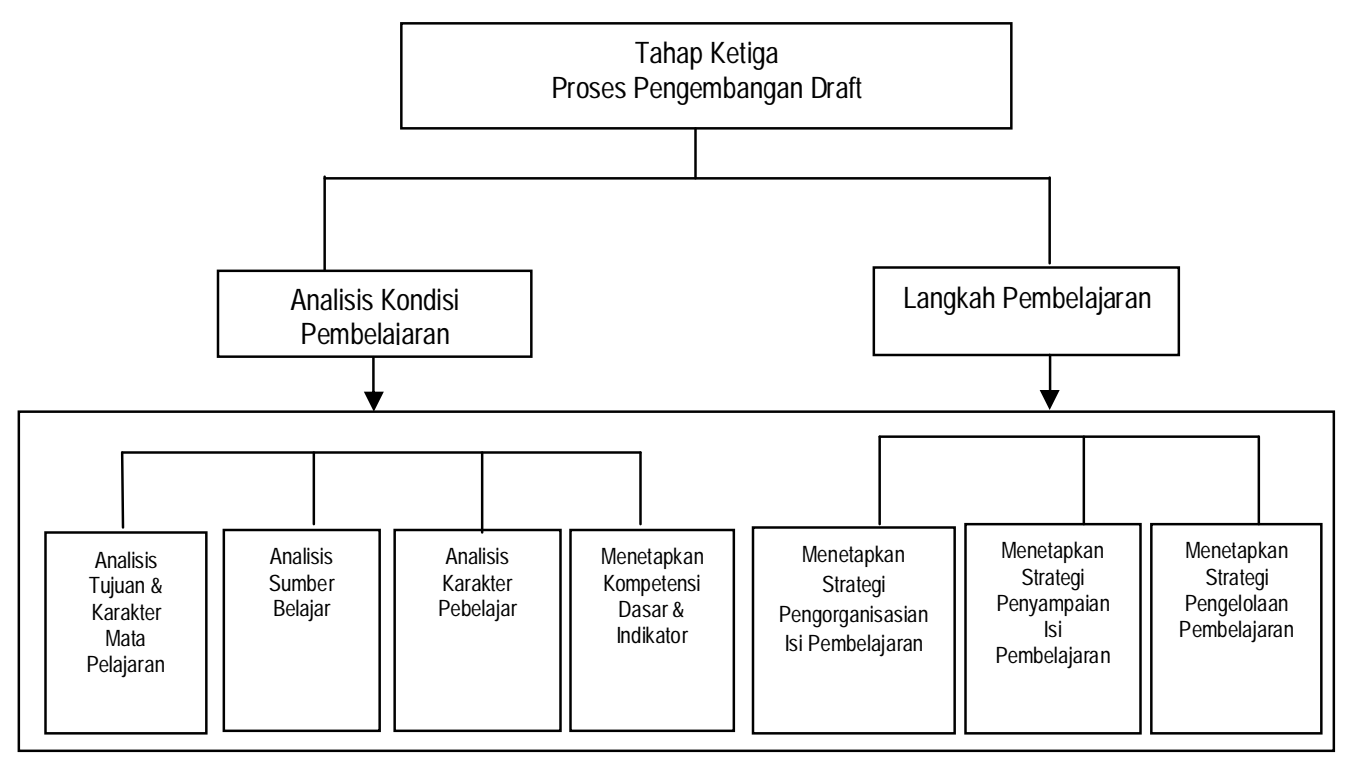

Gambar 3.2 Tahap Ketiga Pengembangan Modul (Trianto, 2007)

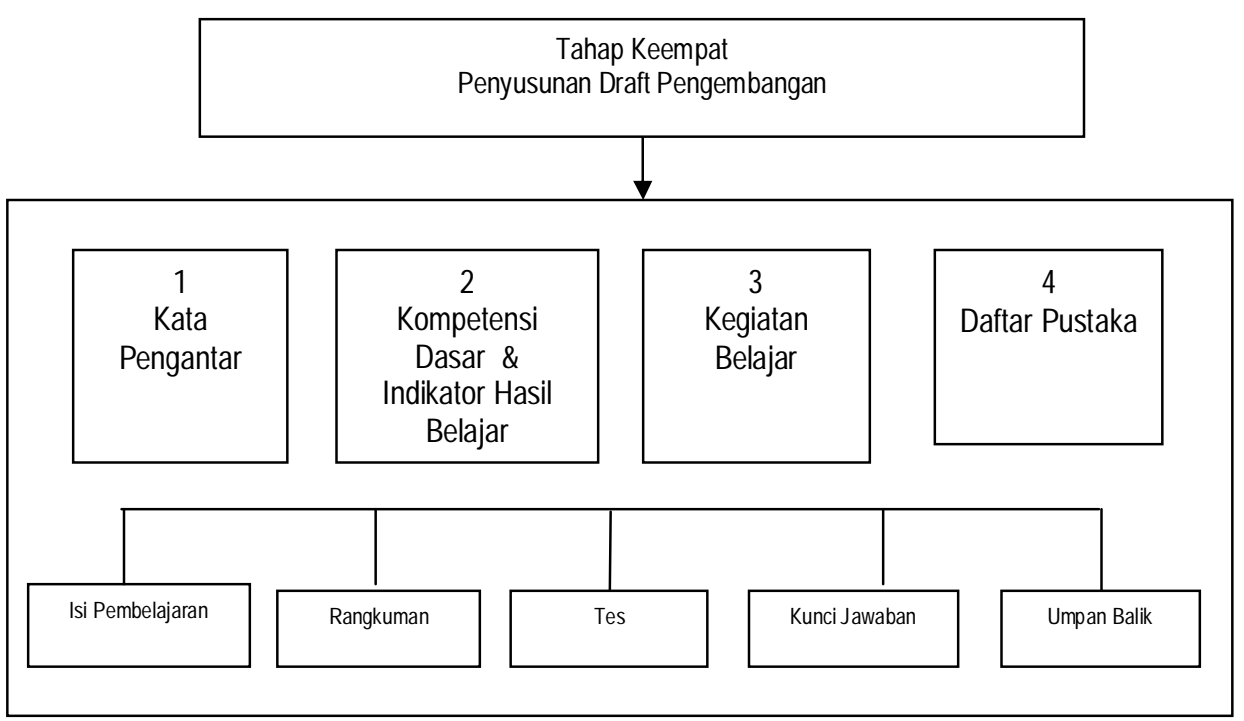

Gambar 3.3 Tahap Keempat Pengembangan Modul (Trianto, 2007) 
ISSN 2089-8673

Jurnal Nasional Pendidikan Teknik Informatika (Janapati)

Volume 1, Nomor 3, Desember 2012

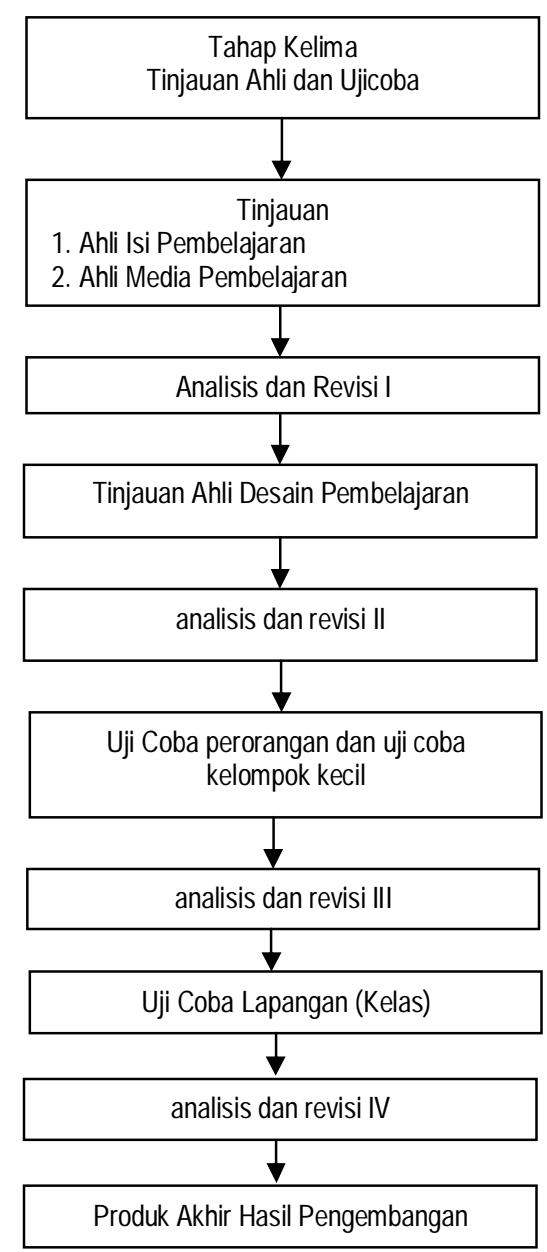

Gambar 3.4 Tahap Kelima Pengembangan Modul (Trianto, 2007) berikut :

Penjelasan tahapan-tahapan untuk pengembangan modul ajar dapat dijabarkan sebagai

a. Tahap Pertama yaitu menentukan mata pelajaran yang menjadi objek pengembangan. Mata pelajaran yang akan dijadikan objek oleh penulis yaitu mata pelajaran aplikasi basis data. 


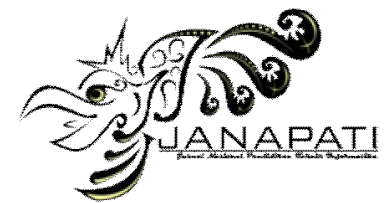

Jurnal Nasional Pendidikan Teknik Informatika (Janapati)

Volume 1, Nomor 3, Desember 2012

b. Tahap Kedua yaitu menganalisis segala sesuatu yang diperlukan dalam pengembangan modul ajar, seperti: Analisis Pembelajaran dan Sumber Belajar

c. Tahap Ketiga yaitu proses pengembangan draft. Pada tahap ini melakukan analisis terhadap pembelajaran dan langkah pengembangan.

d. Tahap Keempat yaitu penyusunan draft meliputi tahap penyusunan modul ajar berupa Kata Pengantar, Kompetensi Dasar dan Indikator Hasil Belajar, Kegiatan Belajar dan Daftar Pustaka.

d. Tahap Kelima yaitu tinjauan ahli dan uji coba terhadap produk yang dikembangkan.

\section{HASIL PENELITIAN DAN PEMBAHASAN}

\subsection{Hasil Pengembangan Modul Ajar}

Tahap pertama yang dilakukan penulis dalam pengembangan modul ajar ini yaitu menentukan mata pelajaran sebagai objek pengembangan. Mata pelajaran yang dijadikan objek pengembangan yaitu Aplikasi Basis Data

Tahap kedua, setelah menentukan objek pengembangan dilanjutkan dengan menganalisis keperluan modul ajar. Pada tahap kedua menganalisis segala sesuatu yang diperlukan dalam pengembangan modul ajar. Analisis pembelajaran dan sumber belajar dilakukan untuk mengetahui buku - buku atau tutorial yang dilakukan oleh guru, langkah langkah atau cara guru dalam sumber belajar diperoleh melalui angket, yaitu angket sumber belajar dan pembelajaran yang diisi oleh guru yang sebelumnya mengajar mata pelajaran Aplikasi Basis Data di Kelas X RPL di SMK Negeri 1 Negara. Dari hasil angket dan wawancara secara langsung dengan guru mata pelajaran Aplikasi Basis Data, sumber belajar yang digunakan guru dalam proses belajar mengajar lebih banyak yang diperoleh dari internet yang disesuaikan dengan silabus dan buku panduan yang dimiliki guru. Siswa belum memiliki modul ajar dalam proses pembelajaran sehingga siswa hanya mendengarkan penjelasan dari guru dan mencatat materi yang diajarkan. Disamping itu juga, pemahaman teori dan praktikum yang dimiliki siswa masih kurang dan waktu yang selama ini diberikan tidak cukup untuk memahami secara mendalam mata pelajaran Aplikasi Basis Data secara cepat. Hal ini menyebabkan diperlukan sekali modul ajar Aplikasi Basis Data. Modul ajar merupakan suatu cara pengorganisasian materi pelajaran yang memperhatikan fungsi pendidikan. Modul ajar ini bisa digunakan sebagai panduan belajar siswa baik di sekolah maupun dirumah, saat ada guru atau pun tidak ada guru di sekolah sehingga siswa bisa memahami teori tentang aplikasi basis data sesuai dengan waktu yang disediakan dan mempraktekkan langsung membuat aplikasi basis data sesuai dengan langkah - langkah yang dijelaskan pada modul ajar Aplikasi Basis Data

Tahap ketiga dilanjutkan dengan proses pengembangan draf. Pada proses pengembangan draf ini dibagi menjadi dua bagian yaitu analisis kondisi pembelajaran dan langkah pengembangan. Analisis kondisi pembelajaran terdiri dari :

1. Analisis Tujuan dan Karakteristik Isi Bidang Studi

Dari hasil wawancara langsung dengan guru mata pelajaran Aplikasi Basis Data, tujuan dari mata pelajaran Aplikasi Basis Data yaitu agar siswa mengetahui perintah SQL, cara membuat tabel, menerapkan query, membuat form, menerapkan makro dan menerapkan reporting. Sedangkan karakteristik dari isi bidang studi yaitu lebih mengarah ke praktikum (fakta) untuk menggali kemampuan siswa.

2. Analisis Sumber Belajar

Dari hasil wawancara berupa angket dengan guru mata pelajaran Aplikasi Basis Data di SMK Negeri 1 Negara khususnya pada jurusan Rekayasa Perangkat Lunak, sumber belajar yang digunakan oleh guru yaitu LKS yang materi sangat terbatas, beberapa buku penunjang yang hanya dimiliki guru sebagai pegangan dan informasi dari internet. Siswa belum memiliki panduan belajar seperti modul ajar yang dapat digunakan sebagai panduan dalam proses belajar siswa baik di sekolah maupun di rumah, dimana siswa dapat membaca dan memahami materi dengan cepat baik berupa materi teori maupun praktikum.

3. Analisis Karakteristik Pebelajar 


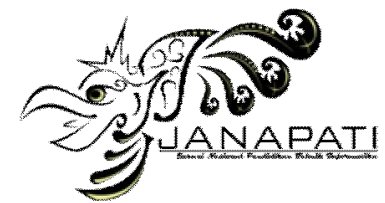

ISSN 2089-8673

Jurnal Nasional Pendidikan Teknik Informatika (Janapati)

Volume 1, Nomor 3, Desember 2012

Untuk mengetahui karakteristik pebelajar penulis menyebarkan angket karakteristik yang terdiri dari 14 pertanyaan. Dari analisis angket karakteristik pebelajar menginginkan adanya modul ajar sebagai panduan belajar karena modul ajar tersebut dapat digunakan sebagai panduan belajar dalam proses belajar Aplikasi Basis Data mereka baik di Rumah dan di Sekolah. Disamping itu siswa sangat mendukung pengembangan modul ajar Aplikasi Basis Data karena mereka ingin belajar materi Aplikasi Basis Data secara sepat dan mudah dipahami baik secara teori maupun praktikum.

Dari angket yang disebarkan kepada 32 siswa terlihat bahwa ketertarikan siswa dengan modul praktikum mencapai $100 \%$, ini menunjukkan bahwa seluruh siswa sangat tertarik untuk mempelajari mata pelajaran Aplikasi Basis Data dengan menggunakan modul ajar. Hal ini disebabkan karena baru pertama kali menggunakan modul ajar dengan teori maupun paktikum sebagai pegangan mereka sendiri karena selama ini mereka hanya belajar melalui LKS, internet, materi yang disampaikan guru dan softcopy materi yang di dapat dari guru yang susah dimengerti oleh mereka karena materinya kurang lengkap dan menggunakan bahasa yang susah di mengerti. Disamping itu juga sesuai dengan jurusan mereka yaitu Rekayasa Perangkat Lunak yang bergelut dalam pengelolaan data menggunakan Microsoft Access pada komputer, sangat perlu sekali mempelajari perintah $S Q L$, cara membuat tabel, menerapkan query, membuat form, menerapkan makro dan menerapkan reporting. Sehingga apabila terdapat data yang dalam pengelolaannya menggunakan Microsoft Access setidaknya tahu, dapat menggunakannya dan sekaligus mengelola data tersebut.

4. Menetapkan Indikator dan Isi Pembelajaran (Tujuan dan Isi)

Indikator yang dirumuskan disini sudah terdapat di Silabus. Kegiatan belajaran yang dibuat dalam 6 bab adalah menerapkan aplikasi basis data yang terdiri dari perintah SQL, cara membuat tabel, menerapkan query, membuat form, menerapkan makro dan menerapkan reporting. Pemetaan silabus ke modul ajar dapat dilihat pada tabel1:

Tabel 1. Pemetaan Silabus ke dalam Modul Ajar Aplikasi Basis Data

\begin{tabular}{|c|c|c|}
\hline $\begin{array}{l}\text { KOMPETENSI } \\
\text { DASAR }\end{array}$ & INDIKATOR & $\begin{array}{c}\text { MATERI } \\
\text { PEMBELAJARAN }\end{array}$ \\
\hline $\begin{array}{l}\text { 1. Menjelaskan jenis } \\
\text { perintah SQL }\end{array}$ & $\begin{array}{l}\text { - Operasi dasar basis data dapat } \\
\text { dijelaskan } \\
\text { Konsep bahasa yang } \\
\text { digunakan untuk menciptakan } \\
\text { obyek-obyek basis data (basis } \\
\text { data, tabel, view, syarat) } \\
\text { dijelaskan. }\end{array}$ & $\begin{array}{l}\text { - Operasi dasar basis } \\
\text { data (Konsep Data } \\
\text { Definion Language) } \\
\text { - DBMS }\end{array}$ \\
\hline $\begin{array}{l}\text { 2. Membuat tabel } \\
\text { basis data }\end{array}$ & $\begin{array}{l}\text { Penggunaan table untuk } \\
\text { membuat tempat menyimpan } \\
\text { record dapat diaplikasikan }\end{array}$ & - Table pada access \\
\hline $\begin{array}{l}\text { 3. Menerapkan } \\
\text { Query pada basis } \\
\text { data }\end{array}$ & 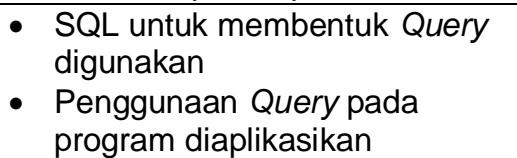 & $\begin{array}{ll} & \text { SQL dan } \\
& \text { penggunaannya }\end{array}$ \\
\hline $\begin{array}{l}\text { 4. Membuat form } \\
\text { basis data }\end{array}$ & $\begin{array}{l}\text { - Penggunaan form untuk } \\
\text { menghasilkan form dapat } \\
\text { diaplikasikan }\end{array}$ & - Form pada access \\
\hline
\end{tabular}




\begin{tabular}{|l|l|l|}
\hline \multicolumn{1}{|c|}{$\begin{array}{c}\text { KOMPETENSI } \\
\text { DASAR }\end{array}$} & \multicolumn{1}{c|}{$\begin{array}{c}\text { MATERI } \\
\text { INDIKATOR } \\
\text { PEMBELAJARAN }\end{array}$} \\
\hline $\begin{array}{l}\text { 5. Menerapkan } \\
\text { macro pada basis } \\
\text { data }\end{array}$ & \begin{tabular}{l} 
- $\begin{array}{l}\text { Penggunaan form untuk } \\
\text { menghasilkan form dapat } \\
\text { diaplikasikan }\end{array}$ \\
\hline $\begin{array}{l}\text { 6. Menerapkan } \\
\text { Reporting }\end{array}$
\end{tabular}$\quad \begin{array}{l}\text { Penggunaan report untuk } \\
\text { menghasilkan laporan } \\
\text { dijelaskan . }\end{array}$ & $\bullet$ Report pada Access \\
\hline
\end{tabular}

Sedangkan untuk tahap langkah pengembangan terdiri dari :

1) Menetapkan Strategi Pengorganisasian Isi Pembelajaran

Strategi pengorganisasian isi pembelajaran yang digunakan penulis mengacu pada pemilihan isi, penataan isi, pembuatan sintesis dan pembuatan rangkuman. Penataan isi dilakukan dengan menyajikan materi dari yang bersifat umum ke khusus, misalnya pada Bab I Perintah SQL penulis menjelaskan secara umum tentang operasi basis data terus dilanjutkan dengan contoh operasi basis data pada kehidupan sehari - hari, 9 operasi basis data dan Database Management System (DBMS). Pada pembuatan sintesis dilakukan dengan mengurutkan tiap-tiap materi yang memiliki hubungan satu dengan yang lainnya serta menyertakan contoh sehingga memudahkan pemahaman siswa. Rangkuman dilakukan oleh siswa dengan mengambil point-point penting dari materi yang telah dipaparkan sehingga mewakili keseluruhan isi materi yang harus dicapai.

2) Menetapkan Strategi Penyampaian Isi Pembelajaran

Strategi penyampaian isi pembelajaran yang ditetapkan penulis didasarkan atas komponen-komponen penyampaian isi pembelajaran yaitu media, interaksi pebelajar dengan media, serta bentuk belajar. Dalam menyampaikan isi pembelajaran dilakukan oleh modul ajar yang di awali dengan gambar - gambar dan diskusi berupa LKS dilanjutkan dengan penyampaian materi pada modul ajar, rangkuman dari materi yang dikerjakan oleh siswa dan soal latihan baik berupa teori maupun praktikum yang dikerjakan secara individu oleh siswa serta bagian akhir setelah siswa menyelesaikan ke 6 bab terdapat tahap merangkum materi secara keseluruhan bab yang dalam hal ini model pembelajaran modul ajar yaitu SQ3R (Survey, Question, Read, Recite dan Review). Media yang digunakan dalam proses penyampaian materi adalah Modul Ajar Aplikasi Basis Data dan komputer masing - masing siswa untuk mempraktekkan langsung materi yang mereka baca serta mengerjakan soal latihan jenis praktikum pada modul ajar.

3) Menetapkan Strategi Pengelolaan Pembelajaran

Strategi pengelolaan pembelajaran yang dilakukan penulis mencakup penjadwalan penggunaan strategi pembelajaran, pembuatan catatan kemajuan siswa, serta pengelolaan motivasi. Penulis menetapkan penjadwalan dalam pengorganisasian dan penyampaian pembelajaran dengan membagi alokasi waktu yang disediakan dan telah dicantumkan di setiap tahap pada modul ajar. Catatan kemajuan siswa dilakukan dengan menggunakan lembar observasi pada saat penugasan. Pemberian motivasi terhadap siswa dilakukan selama proses pembelajaran dengan memberikan nilai pada siswa yang menjawab pertanyaan-pertanyaan yang terdapat pada modul baik berupa lembar diskusi maupun menyelesaikan soal latihan secara individu.

Tahap keempat merupakan tahap penyusunan draft meliputi tahap penyusunan modul ajar berupa Kata Pengantar, Daftar Isi, Daftar Gambar dan Struktur Isi. Pada kegiatan belajar yaitu menentukan isi pembelajaran dengan penjabaran meliputi fase survei, question, read, recite dan review, rangkuman, tes.

Adapun susunan dari modul ajar yang dibuat penulis terdiri dari : 
- Kata Pengantar

- Daftar Isi

- Daftar Gambar

- Struktur Isi

1. Judul Bab

2. Gambar dan Soal LKS

3. Lembar Jawaban

4. Materi

5. Rangkuman Bab

6. Soal Latihan

- Rangkuman Seluruh Bab

- Soal Latihan Seluruh Bab

- Daftar Pustaka

Tahap kelima merupakan peninjauan ahli dan uji coba terhadap produk yang dikembangkan. Pada tahapan ini modul ajar mengalami perubahan - perubahan dari penyusunan draft sebelumnya. Uji ahli isi pembelajaran dan uji ahli media pembelajaran dilakukan oleh dosen pembimbing 1, pembimbing 2 dan guru mata pelajaran. Uji ahli desain pembelajaran dilakukan oleh pemilik percetakan. Untuk uji perorangan melibatkan 2 orang siswa dari kelas XI RPL yang sebelumnya sudah pernah mendapatkan mata pelajaran aplikasi basis data pada saat masih di kelas X RPL. Dan untuk uji kelompok kecil melibatkan 10 orang siswa dari kelas XI RPL yang sebelumnya sudah pernah mendapatkan mata pelajaran aplikasi basis data pada saat masih di kelas X RPL.

\subsection{Uji Coba Lapangan}

Pada saat uji coba lapangan melibatkan siswa kelas X jurusan Rekayasa Perangkat Lunak. Penulis menerapkan penggunaan modul ajar disertai dengan RPP (terlampir pada Lampiran12) pada saat pembelajaran Aplikasi Basis Data, dengan modul ajar siswa menjadi lebih cepat membaca dan mengerti mengenai pembelajaran Aplikasi Basis Data karena lengkap disertai dengan gambar - gambar, lembar diskusi, materi, rangkuman dan soal latihan. Dalam menjawab soal latihan, siswa dapat mengerjakan soal dengan baik berupa soal teori maupun soal praktikum. Dan di akhir bab, terdapat bagian review dimana siswa merangkum sendiri materi secara keseluruhan dari ke 6 bab yang telah mereka pelajari sebelumnya

Berdasarkan pengamatan yang dilakukan, modul ajar Aplikasi Basis Data dapat memicu siswa untuk belajar sendiri di rumah maupun di sekolah dan jika di sekolah, siswa dapat belajar menggunakan modul ajar baik ada guru maupun tidak ada guru.

\subsection{Respon Siswa}

Respon siswa terhadap pengembangan modul ajar Aplikasi Basis Data dikumpulkan dengan menggunakan angket respon siswa yang diperoleh. Berdasarkan hasil analisis skor respon siswa didapatkan kategori yang telah ditetapkan disajikan pada tabel berikut ini.

Tabel 2 Konversi Respon Siswa

\begin{tabular}{|c|l|c|c|c|}
\hline No & \multicolumn{1}{|c|}{ Kelas Interval } & Frekuensi & Prosentase & Kategori \\
\hline 1 & $60 \leq \bar{X}$ & 31 & 88,57 & Sangat Positif \\
\hline 2 & $50 \leq \bar{X}<60$ & 4 & 11,43 & .Positif \\
\hline 3 & $40 \leq \bar{X}<50$ & 0 & $0 \%$ & Ragu-ragu \\
\hline 4 & $30 \leq \bar{X}<45$ & 0 & $0 \%$ & Negatif \\
\hline 5 & $\bar{X}<30$ & 0 & $0 \%$ & Sangat Negatif \\
\hline
\end{tabular}




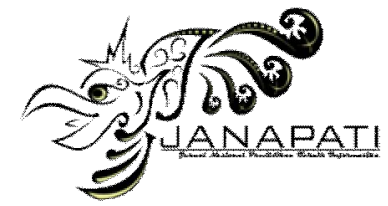

ISSN 2089-8673

Jurnal Nasional Pendidikan Teknik Informatika (Janapati)

Volume 1, Nomor 3, Desember 2012

Respon siswa kelas X Rekayasa Perangkat Lunak Di SMK Negeri 1 Negara terhadap pengembangan modul ajar APlikasi Basis Data tersebar pada kategori sangat positif 88,57 $\%$, positif $11,43 \%$, ragu-ragu $0 \%$, negatif $0 \%$ dan sangat negatif $0 \%$.

\subsection{Pembahasan}

Pengembangan modul ajar untuk mata pelajaran Aplikasi Basis Data dirancang untuk meningkatkan pemahaman siswa tentang materi menerapkan Aplikasi Basis Data baik secara teori maupun praktikum dengan teknik membaca cepat dan mampun dilakukan baik di rumah maupun di sekolah dan saat di sekolah dapat dilakukan baik ada guru maupun tidak ada guru serta mengoptimalkan hasil belajar siswa pada mata pelajaran Aplikasi Basis Data jurusan Rekayasa Perangkat Lunak di SMK Negeri 1 Negara.

Tahapan yang dilakukan penulis selama proses pengembangan modul ajar yaitu tahap penentuan mata pelajaran sebagai objek pengembangan, tahap proses pengembangan draf, tahap penyusunan draf pengembangan serta tahap tinjauan ahli dan uji coba. Kegiatan belajar modul ajar yang dibuat pada modul praktikum ini berdasarkan jumlah kompetensi dasar yang ada yaitu (1) Perintah SQL (2) Membuat tabel (3) Menerapkan query (4) Membuat form (5) Menerapkan makro (6) Menerapkan reporting. Masing-masing kegiatan belajar dalam pengembangannya mengalami beberapa perbaikan. Perbaikan yang dilakukan yaitu dari para ahli dan uji coba lapangan. Para ahli yang dilibatkan yaitu ahli isi, ahli media, ahli desain, guru mata pelajaran Aplikasi Basis Data dan uji coba lapangan dilakukan pada kelas X Rekayasa Peangkat Lunak di SMK Negeri 1 Negara

Susunan modul praktikum ini terdiri dari cover buku, kata pengantar, daftar isi, daftar gambar, struktur isi materi ( judul bab, gambar dan soal LKS, lembar jawaban, materi, rangkuman bab, soal latihan), rangkuman seluruh bab, soal latihan seluruh bab dan daftar pustaka. Sebelum memasuki inti materi, penulis menampilkan gambar - gambar yang berhubungan dengan materi yang nantinya akan menjadi bahan diskusi siswa dengan temannya. Setelah melakukan diskusi dan mengisi lembar jawaban, siswa membaca materi dan mempraktekkan langsung untuk materi yang bersifat praktikum dan kemudian dilanjutkan dengan merangkum materi yang telah di baca dan di praktekkan langsung oleh siswa. Untuk mengukur pemahaman siswa terhadap materi yang di paparkan maka siswa menjawab soal - soal latihan yang terdapat pada modul ajar baik berupa soal teori maupun praktikum dimana yang dalam pengerjaannya bersift individu. Di bagian akhir setelah mereka membaca dan mempelajari ke 6 bab yang terapat pada modul ajar, mereka merangkum materi secara keseluruhan dan membuat ragkumannya pada lembar yang telah disediakan pada modul ajar. Pada akhir modul, penulis mencantumkan rujukan (daftar pustaka) yang digunakan dalam proses penyusunan modul praktikum sehingga siswa dapat mempelajari materi tersebut lebih dalam.

Pada tahap uji coba lapangan, penulis langsung menggunakan modul ajar tersebut pada saat proses pembelajaran Aplikasi Basis Data baik di ruang dikelas maupun di laboratorium. Penerapan modul ajar ini melibatkan guru dan seluruh siswa kelas $X$ Rekayasa Perangkat Lunak di SMK Negeri 1 Negara. Dengan modul ajar Aplikasi Basis Data tersebut siswa menjadi lebih cepat dalam pemahaman pelajaran Aplikasi Basis Data melalui teknik membaca cepat dan guru menjadi lebih mudah dalam proses belajar mengajar dikelas

Untuk mengatahui respon siswa terhadap pengembangan modul ajar Aplikasi Basis Data, penulis menyebarkan angket yang harus diisikan oleh siswa. Dari hasil analisis respon siswa bahwa skor rata-rata respon siswa yaitu 69,11. Distribusi respon siswa terhadap pengembangan modul ajar Aplikasi Basis Data menunjukkan bahwa dari 35 orang siswa kelas $\mathrm{X}$ Rekayasa Perangkat Lunak, 31 orang memberikan respon sangat positif dan 4 orang merespon positif, serta tidak ada yang memberikan respon ragu-ragu, negatif dan sangat negatif. Dari angka tersebut menunjukan bahwa persentase siswa merespon sangat positif yaitu $88,57 \%$ dan $11,43 \%$ merespon positif, serta $0 \%$ yang merespon ragu-ragu, negatif dan sangat negatif. 


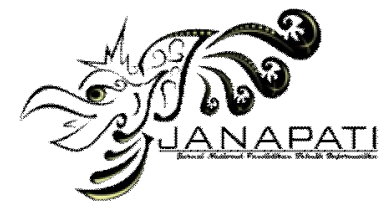

ISSN 2089-8673

Jurnal Nasional Pendidikan Teknik Informatika (Janapati)

Volume 1, Nomor 3, Desember 2012

Dari persentase tersebut, respon siswa terhadap pengembangan modul ajar Aplikasi Basis Data dapat dikategorikan sangat positif. Respon sangat positif tersebut menunjukkan bahwa siswa senang dan termotivasi dalam belajar dengan menggunakan modul ajar. Hal ini disebabkan karena modul ajar ini berisi gambar - gambar untuk bahan diskusi, materi yang jelas langkah - langkahnya dan terorganisasi, terdapat rangkuman dan soal latihan untuk mengukur pemahaman siswa terhadap materi yang telah di paparkan serta bagian akhir dari modul ajar setelah mempelajari ke 6 bab terdapat bagian review, dimana siswa merangkum seluruh materi dari ke 6 bab pada lembar yang telah disediakan. Sehingga siswa lebih mengerti dan memahami isi materi Aplikasi Basis Data.

\section{SIMPULAN DAN SARAN}

\subsection{Simpulan}

Simpulan dari penelitian ini adalah :

a. Pengembangan modul ajar Aplikasi Basis Data kelas X Rekayasa Perangkat Lunak di SMK Negeri 1 Negara dirancang untuk menyediakan sumber belajar bagi siswa sebagai panduan belajar siswa sehingga dapat meningkatkan pemahaman teori dan praktikum siswa tentang pelajaran Aplikasi Basis Data dengan cepat serta mengoptimalkan hasil belajar siswa.

b. Respon siswa terhadap pengembangan modul ajar Apliaksi Basis Data di kelas $X$ Rekayasa Perangkat Lunak Di SMK Negeri 1 Negara yaitu 88,57 \% siswa merespon sangat positif dan $11,43 \%$ merespon positif.

\subsection{Saran} berikut.

Beberapa saran yang dapat diajukan berkaitan dengan temuan penelitian ini sebagai

a. Modul ajar Aplikasi Basis Data ini, masih banyak hal-hal yang perlu diperbaiki karena perkembangan teknologi informasi yang begitu cepat sehingga penggunaan Microsoft Office Access pun semakin berkembang, diharapkan bisa menggunakan yang lebih terbaru dari Microsoft Office Access 2007.

b. Sangat diperlukan modul ajar dengan model pembelajaran SQ3R digunakan karena dapat melatih siswa untuk menyimak gambar, berdiskusi dengan teman, memahami dan mempraktekkan materi langsung, membuat rangkuman materi dan mengerjakan latihan soal dengan cepat. Sehingga mempermudah siswa dalam pembelajaran Aplikasi Basis Data dengan membaca cepat.

c. Penelitian pengembangan ini hanya sampai pada tahap untuk mengetahui respon siswa. Bagi pembaca yang berminat mengembangkan penelitian ini, dapat mengembangkannya sampai dengan tahap pengukuran hasil pembelajaran dan aktivitas belajar siswa. Diharapkan untuk kedepannya dapat dikembangkan kembali modul ajar untuk materi - materi yang lainnya.

\section{DAFTAR PUSTAKA}

Degeng, 1989. Strategi Pembelajaran Mengorganisasi Isi dengan Model Elaborasi. Malang: IKIP dan IPTDI

Dick W \& I. Carey. 1990. The Systematic design of Inttstruction, 3 ed. USA: Harper Cllins

Fisher, 1990. "How To Improve Your Reading Ability: The SQ3R Method. www.google.com 
ISSN 2089-8673

Jurnal Nasional Pendidikan Teknik Informatika (Janapati)

Volume 1, Nomor 3, Desember 2012

Glynn, M.S dan Muth, K.D, 1994, Reading and Writing to Learn Science: Achieving Scientific Literacy, Journal of Research in Science Teaching

Sugiyono, 2011. Metode Penelitian Kuantitati Kualitatif dan R\&D. Bangdung: Alfabeta

Suparmin dan Desy, 2010. Pengembangan Bahan Ajar. Jambi: Universitas Jambi 